\title{
Money, Money, Money? Politico-Moral Discourses of Stem Cell Research in a Grant Allocation Process
}

\author{
Shai Mulinari, Tora Holmberg \& Malin Ideland
}

Concerns have been raised about the marketization of science through the prevailing funding regime. However, the present article will discuss how it comes that the potentially marketable stem cell science is not more commercialized than what is currently the case. We approach this question by analysing discursive pluralism in defining the value of stem cells within a grant allocation process. More specifically, we focus on how the commercial imperative is challenged by other cherished values surrounding stem cell research. The case study used to discuss this is the Swedish Government's funding of stem cell research within so-called strategic research programmes. The analysis focuses on the co-existence of what we refer to as entrepreneurial, translational and basic research politico-moral discourses. How the co-existence of politico-moral discourses is possible, despite potential tensions, is investigated by drawing on the theoretical framework of bio-objectification. Specifically, we highlight how the relationship between various bio-identities and values was reorganized along the research grant allocation trajectory. We argue that there are obvious signs of temporally specific discursive shifts away from the commercial imperative in the grant allocation process. This suggests the need to study located processes, in order to understand the work of politico-moral discourses in the grant allocation process. This work contributes to an understanding of the uneven and varied impact of neoliberal policies on biomedicine.

Keywords: Stem cell, neo-liberalization of science, politico-moral discourse, bio-object, bio-identity

\section{Introduction: \\ The Non-Commercialization of Stem Cell Research}

Stem cells are undifferentiated cells with the potential to develop into more mature celltypes (i.e. differentiation) and the capacity to produce new stem cells (i.e. self-renewal). Stem cells exist both in the embryo and adult organism. A great collective biomedical research effort is underway to elucidate if and how these cells can be mobilized to regenerate damaged tissue, which is a common denominator in a wide array of human diseases. However, looking more broadly in society, stem cells carry various meanings and identities, depending on when and where they figure: as threats 
to the dignity of human life; as intriguing objects of science; as promises for new therapies for severely ill patients; and lately, as connected to and drivers of economic growth. While much work on stem cells within the field of Science and Technology Studies (STS) has engaged with moral and religious contestations (Salter \& Salter, 2007), circulation and space (Wainwright \& Williams, 2008), standardization (Eriksson \& Webster, 2008), expectations (Martin et al., 2008), governance (Gottweis et al., 2009), and commercialization (Plagnol et al., 2009; Martin et al., 2006; Webster, 2013), there is a paucity of studies of national attempts to foster the growth of business through commercialization of academic stem cell research (however, see Salter \& Salter, 2010). Yet policy arguments in support of academic stem cell research often use commercial benefit and job creation as a key justification for permissive policies and increased government funding despite the great uncertainties associated with such projections (Bubela et al., 2010; Caulfield, 2010). Indeed, Gottweis et al. (2009: 23) contend that:

State interests in stem cell research is [...] economically driven in a broad sense, with population health and benefits and clinical applications assigned a secondary consideration.

They argue that states are not only active in securing funding for stem cell research, but are vigorously promoting its commercialization by orchestrating policies aimed at bringing universities and businesses in closer proximity, including favourable intellectual property (IP) regimes, and by guaranteeing the influx of venture capital into the field. Still, at present, there are very few effective stemcell-based therapies commercially available (Daley, 2012).
To approach the question of why there are not more successful commercial stem cell-based therapies than is currently the case, the present article analyzes discursive pluralism in defining the value of stem cells - as a broad category that includes human or non-human stem cells in an embryonic or non-embryonic state - within a grant allocation process and discusses its potential effects. More specifically, we focus on how the commercial imperative is challenged by other cherished values surrounding stem cell research and how this can be understood as a process of "bioobjectification" within certain political and moral economies.

To this end, we draw on STS research concerned with the changing relations between universities, the state and industry in general (Gibbons, 1994; Etzkowitz \& Leydesdorff, 1997; Slaughter \& Rhoades, 2004) and with the commercialization of the life sciences in particular (Sismondo, 2010: 189-195; Rose, 2007). This research has explored how states have developed an assemblage of new techniques of government and governance to foster commercial techno-scientific innovations, including novel funding mechanisms and priorities, increased venture capital influx into high-tech sectors and establishment of technology-transfer offices (TTOs) at universities. In fact, as noted by Cerny (1997: 251) 15 years ago, rather than a predicted decline in state interventions in name of de-regulation, we are facing "the actual expansion of [...] state intervention and regulation in the name of competitiveness and marketization".

For academic researchers working in fields with prospects for innovation, the tendential emergence of a new pattern of state intervention has meant that these researchers have increasingly been cast as "state-subsidized entrepreneurs". Their chief task is to develop commercially 
viable products or services that can boost economic growth and employment in the private sector as well as offer solutions to pressing societal problems, including those related to health (Slaughter \& Rhoades, 2004).

Lave et al. (2010) frame this changing university-state-industry relation and the commercialization imperative against the background of the broad global movement towards neoliberalism that began in the 1980s. A central tenet in this particular strand of STS work is that the rise of neoliberalism has led to major changes in scientific practice, management and contents, i.e. that "neoliberal politicaleconomic relations beyond academia shape what happens within it" (Lave et al., 2010: 664).

Concerns about the impact of neoliberal policies on science in general and biomedicine in particular have spawned a series of case studies, including work on the commodification of biomedical knowledge (Sunder Rajan, 2006; Rose, 2007) and corporate influence over the generation (Mirowski \& Van Horn, 2005), publishing (Sismondo, 2009) and dissemination of biomedical knowledge (Mulinari, 2013).

Notwithstanding the importance of these and other studies highlighting the impact of neoliberal policies on science, it is apparent that the effects of such policies are not uniform but rather uneven, partial and sometimes even contradictory at both the global and local level (Tuunainen \& Knuuttila, 2009; Sanders \& Miller, 2010; Moore et al., 2011). We therefore need more explorations of how these policies fail to align technoscience with the perceived needs of business, including charting the forms of resistance that the commercial imperative encounters. This resonates with Jessop (2002), who urges scholars to be attentive to the increasing dominance of capital in social spheres like science, but also to appreciate that this does not involve a one-sided power relation. Rather, other actors will be varyingly able to limit or resist commercialization and to steer economic activities by imposing their own priorities and modes of calculation.

In the following, we study the uneven and varied impact of neoliberal policies on biomedicine. In order to do this, we depart from a case study: the Swedish Government's funding of stem cell research within so-called strategic research programmes. The national context is thus unmistakably Swedish. However, although the regulatory heritage of national institutions and policies is important to acknowledge, the overall political and scientific context is shared with a number of European countries (Gottweis et al., 2009), and likely with countries outside Europe as well (Salter, 2008). In sum, by investigating discourses of stem cell research in a grant allocation process, we aim to contribute to the burgeoning STS literature on neoliberal governance of science.

The article begins by outlining the theoretical frame, in which the concepts of politico-moral discourses and bioobjectification are delineated. The subsequent section describes the empirical material and the method used. Looking through the lenses of politico-moral discourses and bio-objectification, we then define the predominant discourses that are competing for defining the value of stem cell research, before analysing how these discourses operated during the allocation of public grants to Swedish stem cell research. Finally, consequences for evolving understandings of the uneven and varied impact of neoliberal policies on stem cell research are discussed. 


\section{Theoretical Frame: Politico-Moral Discourses and Bio-Objectification}

Our conceptual frame for approaching neoliberal science policies in regard to stem cell research consists of the twin concepts of political and moral economies of science, on the one hand, and bio-objects and bioidentity, on the other.

We frame the neoliberal governance of science, as discussed above, in terms of political economy. This concept denotes how states organize the production, distribution and consumption of wealth (Jessop, 2002). Following from this definition, the "political economy of science" has been used to designate the production, distribution and consumption of scientific knowledge and artefacts, as well as the policies developed to orchestrate this production, distribution and consumption (Sismondo, 2010). As a corollary to this usage, the political economy of stem cell research can be construed as the production, distribution and consumption of stem cell research, including the role that stem-cell-based products or services play, or are considered to play, in national economies and the related policies and agendas. Closely tied to the term political economy of science is the concept of moral economy of science. In the literature, at least two definitions of moral economy of science are found. One focuses on moral rules (e.g., Kohler, 1994), the other on epistemic values (e.g., Daston, 1995). The latter usage was pioneered by historian Lorrain Daston to address the question of why and how scientists choose to work on certain problems using certain materials, tools and concepts. Specifically, her focus is on historicizing a web of "affect-saturated" epistemic values, such as objectivity, testability, precision, reproducibility, accuracy, explanatory power and simplicity. Moral economies are, according to Daston, upheld by moral or thought collectives and are "integral to science: to its source of inspiration, its choice of subject matters and procedures, its shifting evidence, and its standards of explanation" (Daston, 1995: 6).

Such moral economies are highly resilient to pressure from the surrounding societal milieu, but they can evolve over time. In our understanding, however, the political and moral economies of science cannot be separated other than analytically. Thus the distribution of funding, construction of policies, and the values of scientific knowledge production are intimately connected, as has been pointed out in numerous studies (see for example: Braun, 1998; Mirowski \& Sent, 2002).

In an attempt to synthesize the concepts of political and moral economies, Pestre (2005) introduces the concept of "cités de justices" - or common worlds of moral and political economies - and categorizes a number of such common worlds that work side by side in contemporary life science. As Pestre, we are concerned with how the plurality of political and moral economies is upheld in research - in our case, stem cell research - despite the growing emphasis on the commercialization of knowledge. We do this by looking through the lens of "bio-objectification" (Vermeulen et al., 2012). The term "bio-object" refers to new contested forms of life - for example, transgenic animals, genetically tested foetuses, synthetic biological material, or as in our case, stem cells and stem-cell-derived products and services - that are produced by contemporary bio-medicine. A common characteristic of these bio-objects is that they may challenge prevailing boundaries for example, between humans and animals (such as the xenograft), person and nonperson (experimental human embryos), life and matter (synthetic biology), commodity and non-commodity (patentable/nonpatentable stem cell lines), and thus 
produce governance challenges (Brown, 2009; Hansen \& Metzler, 2012). Given that stem cells can be considered "materialsemiotic figurations" (Haraway, 1997), their materiality as well as the discourses in which they are articulated, must be considered. As bio-objects, stem cells have both internal and social orders and orderings, but they are contingent and shifting (Tamminen \& Vermeulen, 2012). Thus, as stated in the introduction, stem cells come with various applications, negative as well as positive values and possible futures, and as other bio-objects, they are ascribed meaning and value through processes of bio-objectification (Vermeulen et al., 2012). The bio-objectification process involves institutional and discursive work in order to stabilize the, sometimes contrasting, meanings or "bio-identities" ascribed to the bio-object (Holmberg et al., 2011). As a corollary to this, our research task is to track how the multiple and sometimes contrasting bio-identities become established, typically through cycles of negotiations and re-negotiations within and between arenas and through discourses. In sum, the struggle over how to name, frame and govern bio-objects can be called bioobjectification, while the outcome of this process is referred to as bio-identification.

For analytical purposes, we assume that the bio-objectification of stem cells within and between political and moral economies are reflected and reinforced by the "politicomoral discourses" surrounding them. These discourses can thus be viewed as an operationalization of the theoretical frame (see below). Similar to e.g. Hall (1996), who describes how discourses produce sets of available and unavailable subject positions for human actors, we argue that politicomoral discourses on stem cells contribute to constructing their bio-identities: the discourses may limit and enable what characteristics and values are connected to the bio-object. Conversely, we argue that the politico-moral discourses contribute to producing certain positions for the human and organisational actors involved in stem cell research, as well as help articulate the proper and legitimate driving forces in this research. In order to scrutinize the plurality of political and moral economies - reflected and reinforced by politico-moral discourses - we chart the specific values (e.g., epistemic, therapeutic and commercial) ascribed to stem cells throughout a research grant allocation process and describe how the commercial imperative was challenged by other cherished values surrounding stem cell research.

\section{The Case: Strategic Research Funding of Stem Cell Research in Sweden}

The present case study concerns the allocation of funds to stem cell research within so-called strategic research programmes. This research policy reform was part of the Swedish centre-right Government's "Research and Innovation Bill 2009-2012" (Swedish Government, 2008). Essentially, the Swedish Government identified 24 areas, mainly in science and technology, acknowledged as being strategically relevant to society and business. For these areas, approximately $140 €$ million in funding was earmarked for three years. Stem Cell and Regenerative Medicine (SCRM) was one of the strategic areas where vital industries were believed to benefit from public research, and the Bill proposed an addition of $7 €$ million, corresponding to five per cent of the total budget for strategic research, to be distributed by the Swedish Research Council between at least two SCRM projects.

Using the 2008 Bill, the Call for applications for SCRM projects, four ensuing applications (for simplicity these are referred to as Application I-IV in the 
text), and written assessments of these applications by a panel of reviewers, we followed the process of research grant allocation. This set of data is rather unique; thanks to the relatively transparent nature of the Swedish Research Council we were able to scrutinize the full body of data - including research applications and assessments. To complement and contextualize this document analysis, we analysed relevant texts from Swedish authorities regarding the commercialization of SCRM as well as a 2011 public evaluation of the strategic research reform performed by Sweden's Innovation Agency, VINNOVA, in total close to 1000 pages of text.

These texts are empirically and analytically interesting since the "grantgenre" (including call, applications, reviews and evaluations) is supposed to exclude contradictions, leaving the messages clear and coherent. Therefore, the discursive conflicts - when they appear - remain implicit. Such conflicts may be a reflection of different sub-genres within this "grant genre". Thus different sub-genres invite different discourses to "play" (Fairclough, 1995); for example, the Call is clearly attuned to a more explicitly political sub-genre while the applications are more scientific. Still, we find it important to analyse how one outcome of such discursive conflicts is that the commercial imperative is challenged by other cherished values surrounding stem cell research.

Moreover, to investigate challenges associated with stem cell research and commercialization, and to clarify and supplement documentary findings, we included semi-structured interviews with three stem cell scientists associated with the projects that received strategic funds, two supervisors of life science commercialization at the respective university's TTOs, and a former CEO of a major Swedish stem cell corporation, thus a total of six interviews. The interviews were performed in Swedish during 2012 by two of the authors, and quotes when appearing in the article have been translated and anonymized. By combining these document and interview sources, we intend to shed light on the politico-moral discourses presently employed to make sense of stem cell research. In turn, as proposed above, this may provide a window into how the values of stem cell research and of the cells themselves are negotiated between different political and moral economies. Moreover, by investigating politico-moral discourses, we aim to shed light on the process of bioobjectification insofar as stem cells are attributed specific bio-identities in various discourses. In other words, through the discursive struggle of bio-identification, various identities get stuck to the stem cell bio-object.

In a first step of the discourse analysis, we identified three competing discourses on the value of stem cell research and stem cells as objects: 1) The entrepreneurial discourse; 2) The translational research discourse and; 3) The basic research discourse. These three discourses are unlikely to be the only ones operating in the grant allocation process, but they emerge as dominating in the data as a whole. The next section describes how the discourses were defined and analysed. In a second analytical step, we considered which bio-identities were made available, attached and valued with respect to stem cells in these discourses. In a third and final step, we investigated how the relationship between various bio-identities and values was reorganized along the research grant allocation process, i.e. how temporality imposed on the bio-objectification trajectory.

\section{Three Politico-Moral Discourses}

In this section we present three politicomoral discourses that emerged as dominating in the grant allocation 
process: the entrepreneurial discourse, the translational research discourse, and the basic research discourse. The aim is to exemplify how these discourses are naming and framing the stem cells towards certain bio-identities.

In the entrepreneurial discourse, stem cells emerge mainly as putative commodities. While the entrepreneurial discourse is strongest in the Research and Innovation Bill, it was propagated well beyond this political document. Consider the following excerpt from the reviewers' assessment of SCRM Application III, that revolved around activation of endogenous stem cells to regenerate damaged tissue and nerves in vivo, and culturing and differentiation of stem cells into transplantable complex tissues in vitro.

\begin{abstract}
The creation of improved therapies will likely be accompanied by intellectual property that may be of commercial value. This may translate to the generation of start-up companies that will increase the international impact of Swedish Regenerative Medicine industry. [...] Therefore these research projects can be viewed as the pipeline, providing new technologies that will benefit patients and provide opportunities for the development of start-up companies or industrial collaborations. (Swedish Research Council, 2009b: 208)
\end{abstract}

Here, stem cells' commercial values are essential to their bio-identity: Stem cells are appreciated insofar as they can be traded on a market for profits, job opportunities, or national competitiveness. This commercial value is at the same time positioned in relation to the future benefit for patients, the lead motif of the next dominant discourse.

The second politico-moral discourse revolves around how strategic research will bring about therapeutic advances within the (public) health care system. Here, stem cells' clinical values and therapeutic bio-identities are foregrounded: The cells are attributed value insofar as they can be employed in the clinic, for example as stated in the following assessment of SCRM Application III:

The CREATOR program is a rich basictranslational environment with scientists who are primarily interested in the "bench to bedside: bedside to bench" paradigm that is very effective in accelerating research in clinical applications. [...] The investigators have targeted clinical applications where there is clear unmet needs. For instance, the prevention of infection in corneal grafting or the improvement of fracture repair or wound healing will be quite important. (Swedish Research Council, 2009b: 208)

This translational research discourse mirrors in many respects the entrepreneurial discourse, but with another arguably more altruistic goal in sight: improving patients' health. As such, this goal relies on successful and thus highly cherished translational research.

If stem cells were something that could be tamed and packaged into a commodity by entrepreneurial research, and turned into a therapeutic breakthrough by translational medicine, the stem cells in the basic research discourse take the shape of something that is yet to be perfectly understood - something that must be further explored and explained. Consider the excerpt below from the assessment of SCRM Application I. Here, the emphasis is on stem cells' epistemic bio-identities, i.e. the cells have intrinsic value as objects of knowledge - which should be discovered, investigated, followed and understood. 
Decoding cell lineage at the organism level. This is certainly the most original component part of the proposal and from the fundamental point of view the most interesting [...] A group of PIs at the Institute proposes to follow the lineage relationship in intact organisms by following the evolution of polyguanine repeats. This procedure can be done at the single cell level and will be useful not only in tracing the progeny of cell, deducing tissue regeneration, and tracing progenitor cell compartments, but also in anticipating tumour relapse. (Swedish Research Council, 2009b: 209)

Arguably, this discourse could be characterized as more traditionally academic: Scientific progress derives from curiosity, the search for mechanistic explanation, and a will to know the world through experimentation, rather than striving primarily towards commercial or clinical ends - although commercial and clinical output may often be seen as welcomed by-product of science (Styhre \& Sundgren, 2011).

\section{Discursive Shifts in the Grant Allocation Process}

While these discourses are made explicit throughout the grant allocation process, they operate, as we show below, with different emphasis along the trajectory, i.e., in the (1) 2008 Research and Innovation Bill, (2) Call for applications, (3) SCRM project applications, (4) Panel assessments, and (5) 2011 Follow-up evaluation of the strategic research reform. In the section below, we analyse the interplay between the three politico-moral discourses and demonstrate a shift from a strong focus on commercialization towards therapeutic and epistemic concerns and values in the grant allocation process - an orientation later challenged in the 2011 follow-up evaluation and the subsequent 2012 Research and Innovation Bill from the centre-right Government.

\section{Research and Innovation Bill: Ushering Commercialization}

In 2008, the Swedish centre-right Government presented its Research and Innovation Bill for 2009-2013 (Swedish Government, 2008). The subtitle - $A$ boost to research and innovation - indicated a main concern with converting state investments in public research into commercially viable innovations for industry. As such, the Bill should be viewed against the background of the current political consensus on state policies aimed at boosting national industrial competitiveness in high-tech sectors. Accordingly, the Government opened the Bill by emphasizing that,

In today's era of globalization, Swedish competitiveness must be largely based on our exports having a high level of knowledge content, which is why research, development and innovation are central components of our growth policies (Swedish Government, 2008: 14).

The Bill also expressed concerns about an alleged history of repeated failures in commercializing academic research. To amend this, several reforms were suggested. On a general level, the Government proposed increased research funding, especially for research with commercial prospects. In parallel, faculty should be legally required to report any commercializable results to their home universities. Moreover, entrepreneurial activities should be fostered "through increased access to public risk capital" (Swedish Government, 2008: 126) and through financial support for TTOs. 
However, the primary research policy innovation was the earmarking of money for so-called strategic research - a political programme for orienting academic research towards commercial outcomes ${ }^{1}$. In light of recent debates on the shift in national research policies from basic research to research aimed at increasing industrial competitiveness, and on the potential conflict between epistemic and commercial values or priorities in public research, it is interesting note how this tension was treated in the Bill.

It is of vital importance that those seats of learning granted funds for a strategic venture give scope to free, curiositydriven research within the framework of the strategic area. It is also important that representatives of society and industry in the relevant areas be allowed to participate in formulating research questions and that companies be made part of the project and participate in carrying it out. This will result both in solid research results and in the application of proficiencies. (Swedish Government, 2008: 68)

Thus, according to the Swedish Government, there was no immediate conflict between cherishing curiositydriven research and simultaneously stating that other stakeholders, particularly industry, should be involved in formulating research directions. Rather, basic research was seen as a prerequisite for commercial application. However, while the value of "curiosity-driven research" was defended in the Bill, the projects' commercial aspects should still to be considered decisive when allocating strategic funds. Indeed, all applications for strategic funds were to contain specific sections detailing the project's relevance and connection to Swedish business, including strategies and plans to commercialize research, and existing supportive entrepreneurial capacities. Moreover, while the Bill repeatedly stressed the importance of the selected strategic areas to business and society, as regards to policy initiatives these were basically all aimed at facilitating the flow of ideas and products from academia to business (e.g. faculty should be legally required to report any commercializable results to their home universities; increased access to public risk capital and support to TTOs). There were no complementary policies proposed for facilitating the flow of non-commercializable ideas and products from, for example, biomedical research to clinical settings.

Arguably, therefore, the Government effectively touted entrepreneurial research as an obligatory passage point between basic science and patients/consumers. This is consistent with the contention that state policies have moved "from an ideology that defined the public interest as best served by shielding public entities from involvement in the market, to one that saw the public interest as best served by public organizations' involvement in commercial activities" (Slaughter \& Rhoades, 1993: 287). Within this neoliberal ideology, strongly associated with the entrepreneurial discourse, stem cells, as other bio-objects, gain legitimacy insofar as they can be transformed into commercial objects, with health benefits being cast as a result of effective marketization. To illustrate this, Figure 1 schematically outlines the policy pattern that permeates the Bill. This pattern is expressed, first, through the idea of sequential translations from epistemic values to commercial and then to clinical values and, second, by the primacy of the commercial bio-identity.

In the next two sub-sections, we explore how these associations between epistemic, commercial and therapeutic values were 


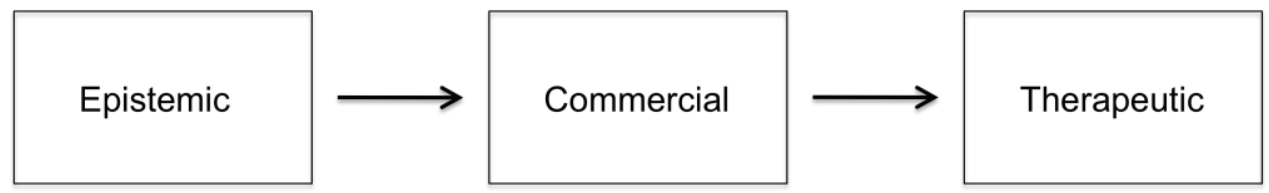

Figure 1. Representation of view expressed in the Swedish Government's 2008 Research and Innovation Bill. Values and translations between values are indicated.

reorganized along the SCRM research grant allocation process.

\section{Call for Proposals: Making Room for the Therapeutic Bio-Identity}

In addition to the more general political programme revolving around entrepreneurship, commercial innovation and economic growth, the Bill contained specific sections on each of the 24 strategic research areas detailing the reasons for the Government's decision to allocate funds ${ }^{2}$. These texts formed the basis for the Call for grant Applications. The Call clarified that all submitted project applications were to be judged based on two categories of criteria:

1) that the research should achieve the highest quality in an international comparison, and 2) concurrently it should be of strategic importance for society and the business sector. The fundamental criterion, however, is scientific excellence (existing capacity or the potential to achieve scientific excellence in international comparison). (Swedish Research Council, 2009a: 3)

It is at this junction that we discern the first sign of a downplaying of the primacy of commercialization, which we propose is associated with increased articulation of the translational and basic research politicomoral discourses. Thus, in the Call for SCRM projects - in which Regenerative Medicine was cast as "an area of application" for stem cells (Swedish Research Council, 2009a: 21)
- epistemic, clinical and commercial ends were given at least equal prominence. This was stated in the SCRM Call as follows:

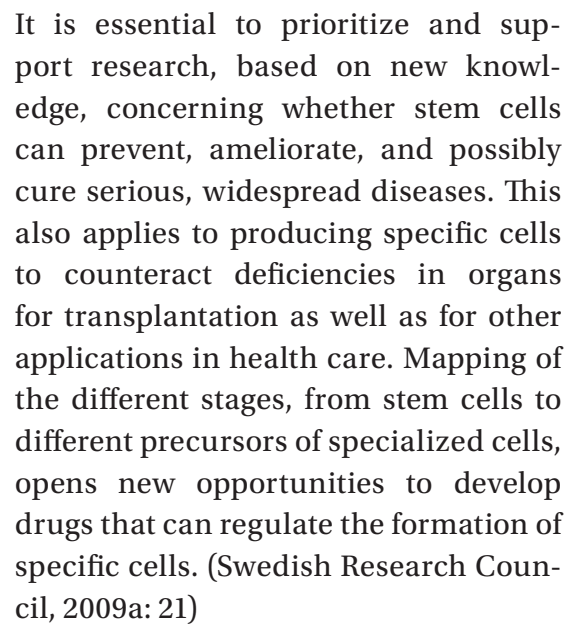

We also suggest that this shift from predominantly commercial considerations is associated with the forging of a different set of associations between epistemic, commercial and therapeutic values. Instead of the idea of sequential translations present in the Bill, we discern a conceptualization of scientific progression characterized by parallel translations from epistemic to commercial and therapeutic values, respectively (Fig. 2). In other words, stem cells can be translated either into a commodity or therapeutics, or both. Importantly, in this pattern, entrepreneurial research and commercial values are possible but not obligatory passage points between basic science and patients/consumers. 
Figure 2. Representation of view expressed in Call for SCRM project proposals. Values and translations between values are indicated.

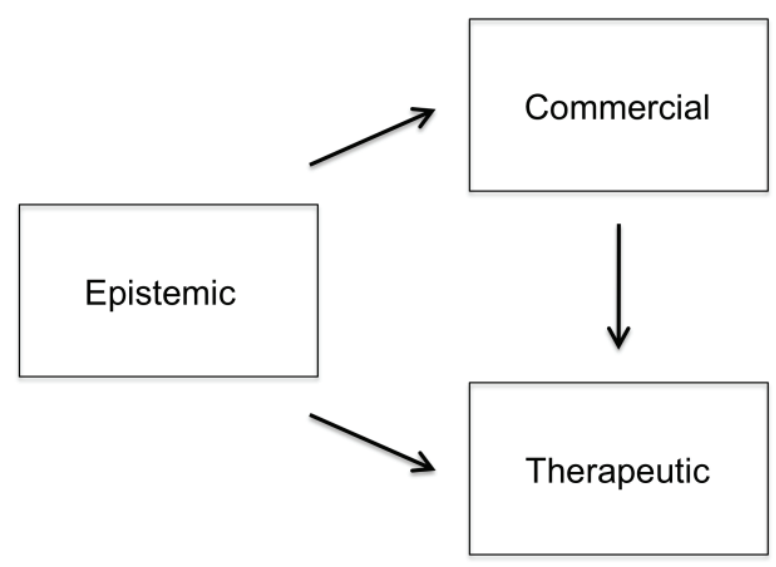

\section{Proposals and Assessments: Upgrading the Epistemic Bio-identity}

Unsurprisingly, given the difficulties associated with commercialization and therapeutic innovation, the SCRM applications centred on basic research efforts to improve knowledge in stem cell and developmental biology, i.e. there was a strong articulation of the basic research politico-moral discourse and the epistemic bio-identity. What was perhaps more surprising then, in light of the political pressure to commercialize, was that the applications stressed clinical possibilities and challenges more forcefully than commercial ones. We illustrate this by focusing on the two applications that received the highest ranking by the panel of reviewers and that hence received funding (referred to as Application I and II).

Application I suggested the establishment of a Centre for Regenerative Medicine,

with the vision of conducting research leading to development of new concepts in stem cell biology and new therapies in several disease areas.

As explained in the application abstract, it centred on five programme areas which integrate basic and clinical science:

1) Molecular basis of cellular differentiation.

2) Steering stem cell differentiation.

3) Transplantation biology.

4) Development of novel technology to trace cell lineage at an unprecedented, organism-wide level.

5) Integration of biomaterials and nanobiology with stem cell research.

In sum, the application focused on basic research in stem cell and developmental biology (points 1, 2, 4), improving current methods and protocols for stem cell differentiation, culturing and expansion $(2,5)$ and advancing transplantation biology in clinical settings (3). Commercial considerations and prospects were not explicitly mentioned in the abstract. Nor was commercialization explicitly mentioned in the reviewers' summary assessment, which instead centred on epistemic and therapeutic prospects within a bench-tobedside, bedside-to-bench paradigm aimed at integrating basic research and clinical work: 
There are few institutions with such a combination of experts in regenerative research that combine a very strong basic research interest with an immediate application to the patient. A very strong aspect of the proposal is the lineage tracing programs which are innovative and will be extremely useful to understand the physiological role of different cell types in tissue repair and also in the follow up of tumours. (Swedish Research Council, 2009b: 210)

Here, excellence in the investigators' track record was valued, along with epistemic and therapeutic values combined with an innovative methodology. One of the central figures in this research milieu confirms these priorities in an interview, stating that:

This is basic research in well, we don't make any patient, we don't test new drugs on patients or anything like that. Instead we try to understand how things work. Even though we're very interested in contributing to some kind of therapeutic development as well [...] Well, I think that... a combination of basic understanding of how the body normally functions and how to modulate it in order to develop regenerative therapies, is what is fun, or, well, the possibility to perhaps contribute to the development of regenerative treatments. (Stem Cell Scientist 1)

What becomes positively valued ("what is fun") is to understand normal and abnormal physiology ("how things work"), with the prospect of helping patients ("the development of regenerative treatments"). In the interview, the pros and cons of entrepreneurship were also discussed. The scientist was very positive about the possibilities of commercialization, but mainly as means to secure additional funding for basic and clinical research.

Turning to Application II, the constellation of researchers summarized their intentions as follows:

The overall objectives within the next 10 years are to demonstrate at least in one disease, i.e. diabetes, that stem cell-based cell replacement therapy is effective and safe, to provide therapeutic candidates for stroke and haematological diseases, and to build a strong base of knowledge about stem cells and disease mechanisms to pave the way for future efforts to devise new clinically effective treatments.

Thus, compared with Application I, therapeutic values were stressed more than epistemic ones (the "strong knowledge base" aiming at paving the way for "new clinically effective treatments"). Moreover, unlike Application I, commercialization was mentioned in the abstract alongside clinical translation:

The objectives will be of strategic importance for both the Swedish society and industry. Swedish scientists will take a leading role in the development of novel stem cell-based therapies for serious diseases, and, hence, provide solutions to important health problems in society. Generated new knowledge will be translated into commercial products.

In the Call, as noted above, the commercial output - or "bio-value" (Waldby, 2002) - of the epistemic labour was stressed. However, as one of the scientists in the milieu told us, commercialization was not uncontroversial; it was increasingly demanded from "above" and involved certain risks: 
Now they require commercialization and patenting if you want to have a... get grant money or a position or whatever. And everybody needs funding and positions to do their research. And so you have to do it. To get the right qualifications. And so maybe you focus on something you can patent rather than on something that will generate the real and important discoveries. (Stem Cell Scientist 2)

The problem of orienting research towards commercial outcomes and valuing a less legitimate object - the commodity - was stressed ("focus on something you can patent"). Later in the interview, the scientist added that this did not imply that their research results should remain only within the remit of the university, but that like all research it should serve society at large. However, to achieve that goal, the research cluster had chosen to focus more on the translational dimensions of their research than on commercialization, which was also confirmed by Stem Cell Scientist 3, working in the same research cluster.

This contention, that the applications stressed epistemic and clinical possibilities and challenges more forcefully than commercial ones, is further supported by the assessment made by the panel of reviewers. While enthralled by the epistemic prospects of the two applications and by the possibilities for clinical translations, they were less impressed by the entrepreneurial strategies and existing structures to support commercial exploitation. For example, Application I was criticized for having

limited relationships with biotechnology and Big Pharma companies at the present time (Swedish Research Council, 2009b, p. 210)

and Application II was chided for having too little venture and business capital influx. The latter project was described as possible to commercialize, but with a hint that it would become expensive and that more capital was needed (Swedish Research Council, 2009b).

Taken together, our analysis supports the idea that a certain shift from the commercial imperative took place through the grant allocation process. This orientation, we propose, is associated with an insistence by researchers and reviewers on the epistemic and therapeutic value of stem cell and developmental biology research and an emphasis on therapeutic and epistemic outcomes over and above commercial ones, i.e. with a downplaying of the entrepreneurial politico-moral
Figure 3. Representation of view expressed in SCRM project proposals and assessments. Values and translations between values are indicated.

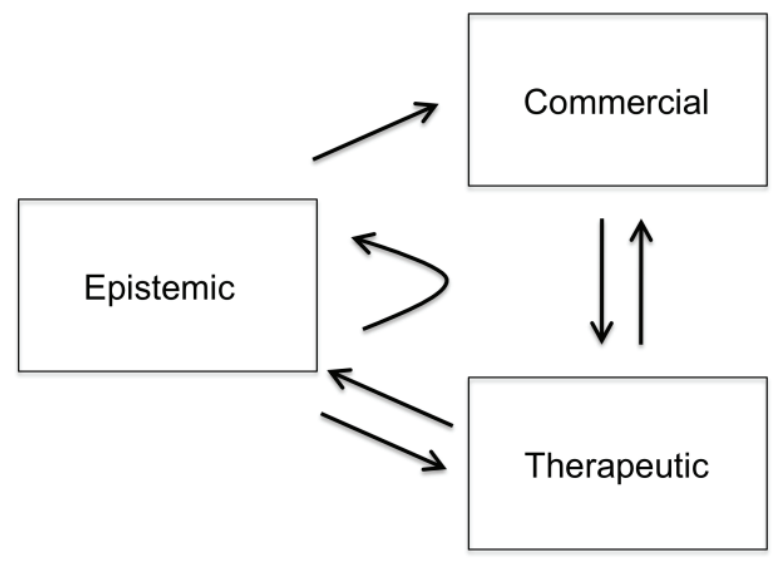


discourse. Schematically, as delineated in Figure 3, we suggest that (1) in addition to the idea of parallel translations from epistemic to commercial and therapeutic values, respectively, already present in the Call, the applications and assessments are characterized by the idea of an epistemic loop, i.e., more knowledge about stem cells is needed to boost basic research; (2) there are translations in the texts not only going from epistemic to therapeutic values, but also in reverse from therapeutic to epistemic values (i.e. the bench-tobedside, bedside-to-bench paradigm); and (3) commercialization is at times framed as a by-product of clinical application rather than the other way around, as was the case in the Bill.

\section{Follow-up Evaluation and the New Bill: Coming Full Circle}

Thus far, our analysis has shown how the entrepreneurial discourse was challenged by translational and basic research discourses through the grant allocation process. These discursive shifts also made room for other bio-identities and different values of the stem cells. According to our informants at TTOs preoccupied with the commercialization of biomedical research, there was a lack of commercial commitment among certain researchers. This was, in their view, due partly to genuine disinterest - a lack of the "entrepreneurial spirit" as a TTO manager put it - and partly to specific difficulties associated with stem cell commercialization. In brief, stem cell research is difficult to commercialize because it does not fit easily into current business models in the life sciences that revolves around chemically synthesised drugs. Moreover, the stem cell patent landscape is tricky terrain. This latter point was explained to us as following:
I'm not so up on stem cells really, but the little I know is that there are many steps that have to work. And say he [talking about a stem cell scientist] solved one part, then he's still dependent on a whole lot of other patents earlier in embryonic development, differentiation. So it's pretty hard to navigate all that, as I see it, to find the freedom to operate and who else is interested and such things. (TTO manager 1)

Getting a stem cell patent is, in the TTO manager's view, contingent on many steps. In particular, the challenge is not only to isolate a sufficiently novel aspect of the stem cell bio-object that can be patented without infringing on existing patents, but also to find a commercial application that is not curtailed by existing patents on prior or subsequent steps in a cell differentiation trajectory, for example from embryonic stem cell to insulin producing pancreatic beta cell. It should be noted, however, that SCRM is not unique in having commercialization difficulties - at least if we are to believe a 2011 follow-up evaluation of the conditions for innovation in the areas of strategic research, performed by Sweden's Innovation Agency, VINNOVA (2011). According to them, industry and other organizations had, overall, "been involved to a limited degree or not at all in a dialogue about research priorities" in assessed research projects and that "there was no direct incentive and follow-up criteria for this and, moreover, the venture has not generated new, expanded or deepened collaboration" (VINNOVA, 2011: 3). VINNOVA concluded their evaluation by saying that one should

not expect the strategic research venture to contribute to any great extent to the generation of innovations in the participating organizations, because 
direct collaborative relationships are a necessary prerequisite for an effective exchange of knowledge (VINNOVA, 2011: 3).

The evaluation is pertinent to the present argument not only because it supports our contention of shifts in the grant allocation, but also because it outlines a possible neoliberal policy response to this. Thus, to amend this alleged commercialization failure, VINNOVA recommended that the Government establish a "strategic innovation programme" in which

[a]ctors from industry and society should play important roles in making research priorities in the same was as university researchers play important roles in establishing strategic research priorities (VINNOVA, 2011: 4).

And, indeed, in the Research and Innovation Bill from 2012 this was exactly what was proposed: A new research policy instrument denoted "strategic innovation areas" in which increased intermingling between the academy, business and the state would be fostered through co-funding mechanisms (Swedish Government, 2012). For Government, co-funding was seen as a way to prioritize research already selected by businesses (or other financially strong actors) as evidenced by their financial commitment to the project. If effective, this neoliberal research policy instrument will put a premium on academic research aligned with the expressed needs of big business and, arguably, possibly further curtail opportunities for epistemic and therapeutic values to take a centre stage through the basic and translational politicomoral discourses as addressed in this paper.

\section{Conclusion}

We began this article by noting that one of our main concerns is with how neoliberal policies impact on the topography of stem cell research. As we have shown here, the science political commercialization imperative, strongly associated with the entrepreneurial discourse, may be challenged by translational and basic research discourses within a grant allocation process. Notably, these politico-moral discourses are highly unlikely to be unique to stem cell research, or even to biomedical research, but probably exist throughout a wide range of fields of research (cf. Pestre, 2005).

At this juncture it is important to again point out that while the entrepreneurial discourse is not the only one present it the Bill, it still constitutes the primary discourse insofar as other discourses (translational, basic research) gain legitimacy directly or indirectly in relation to it. This is seen for example in the legitimization of noncommercial science by claiming that it indirectly contributes to the overall competitiveness of the life science sector or of a region. A similar argument is put forth by the Innovation Agency VINNOVA that perceived basic stem cell science to be of such importance for business development that basic research in the field should be subsidized by the state rather than left to the vagaries of the market (Rickne \& Sandström, 2009) (see note 2). This resonates with Jessop's contention that the increased importance of structural competitiveness and/or systemic competitiveness leads to a fundamental redefinition of the "economic sphere" because many phenomena previously regarded as "extra-economic" are now seen as directly economic and/or economically relevant (Jessop, 2002: 135).

Through the discourse analysis performed, we showed how the 
entrepreneurial, translational and basic research discourses co-exist and mingle even though the different values they promote occasionally come into conflict. Here, we suggest that the intermingling of discourses results in negotiations over the values of stem cell research and stem cells. This contention is supported by the way the various values ascribed to stem cells became reorganized along the research grant allocation process, as schematically outlined in Figures 1-3. Thus, rather than loudly opposing the commercial imperative, we have argued that stem cell researchers displaced it by emphasising: the need for more knowledge about stem cells to boost basic research, the bench-tobedside, bedside-to-bench paradigm, and by framing commercialization at times as a by-product of clinical application rather than the other way around.

This analysis is consistent with the idea of temporally specific epistemic and clinical shifts in the grant allocation process. Thus, commercial imperatives are strong in the Bill, but shrink throughout the grant allocation process while epistemic and therapeutic identities and values are foregrounded. This could be interpreted as suggesting the need to look at both time and place, that is, to study located processes, in order to understand the work of discourses in science policies. Crucially, this is what the framework of bio-objectification aims at, since a focus on conflict - however implicit it may be - challenges the common idea of implementation of policies as top-down:

However, debates and controversies on these innovative entities, as well as on the technologies and practices that help to make and to sustain them, suggest that the process of bio-objectification should not be understood as a one-way street. Such debates include, on one hand, controversies on who or what is amenable to be "objectified" - and how, but also less vociferous debates in which scientists, policy-makers, and other groups of actors discuss how to order these entities, who to entrust with their oversight, and in light of what sort of principles. (Hansen \& Metzler, 2012: 80)

We have also pointed out how the stem cell bio-object may eschew commodification, despite a seemingly hegemonic entrepreneurial discourse in science policy and a strong political will. Thus our informants repeatedly underscored some specific difficulties, including difficulties related to the intricacies of stem cell biology and mismatches between proposed models for stem cell therapeutics and the current commercial models of Big Pharma that revolves around chemically synthesised drugs. Moreover, as the Reviewers of the SCRM proposals noted, commodification of academic stem cell research is likely to require increased private sector investments and support. As a result of such difficulties, apart from hematopoietic stem cell transplantation, essentially all other stem cell treatments remain experimental or are practiced in the absence of standard clinical evidence of benefits and safety (Lau et al., 2008). Ostensibly, the issue at stake here is whether the stem cells can be made to fit, or if the commercial models themselves will change.

Finally, we would like to reconnect this concluding discussion to our initial outline of the sets of values that prevail in the different political and moral economies of science - or "cités de justices" (Pestre, 2005). One advantage of analytically connecting political and moral economies to the concept of bio-objectification is that this approach allows us to grasp how the commercialization imperative is, if not resisted, at least offset by the tenacious 
political and moral economies of science (Daston, 1995). Thus, by adding the concept of "politico-moral discourses" to the framework of bio-objectification, we were able to point out how the relationship between various bio-identities and values were reorganized along the research grant allocation process. In this way, our work may contribute to the understanding of the varied and uneven impact of neoliberalism on science: the total marketization of academic research might not be possible, partly because, as argued here, there are diverse political and moral economies of science at work, conflicting discourses in operation and bio-objects that, at least thus far, eschew commoditization. Clearly, more knowledge is needed regarding how the various political and moral economies of science interact, and if and how political and moral economies are changing due to the pressure to commercialize scientific results. Conversely, more knowledge is needed regarding if and how the various barriers - scientific, economic, social, and legal - facing stem cell research commercialization are strengthening a political and moral economy that cherishes epistemic and therapeutic values over and above commercial ones.

\section{Notes}

1 This earmarking of money to strategic research represents an extension of the research policy reforms initiated by the previous centre-right Government in 1994 with the establishment of a set of new foundations, using money from the so-called wage-earner funds, to foster new alliances between academia and industry (Benner \&
Sörlin, 2007). Thus, these foundations - like the strategic research - would "create new environments that would be conductive to both basic science and economic growth" (Benner \& Sörlin, 2007: 35). For example, one of these foundations, the SSF, funded a set of large "centres of excellence", the objective of which was to foster "strategic relevance for the present and future industry" and "an integration of basic and applied research" (cited in Benner \& Sörlin, 2007: 40).

2 The Government's selection of SCRM as a strategic area was preceded by commissioned analyses of business opportunities in the area. Thus the text "Swedish possibilities within tissue engineering and regenerative medicine" produced for the Swedish Innovation Agency VINNOA argued that, for Sweden to excel in the area, a coordinated and strategic effort from the state was needed "to complement the present funding of projects, centres and cluster development the field is receiving through the Swedish $R \& D$ funding system and lead to a more pronounced effect on research and innovation in this field" (Rickne \& Sandström, 2009: 16).

\section{Acknowledgements}

The authors are thankful to the financial support by Riksbankens Jubileumsfond (Dnr 2010-001) and Crafoord Foundation. Further, we wish to acknowledge the intellectual environment of the COST Action "Bio-objects and their boundaries" (ISI0001). 


\section{References}

Benner M \& Sörlin S (2007) Shaping Strategic Research: Power, Resources, and Interests in Swedish Research Policy. Minerva 45(1): 31-48.

Braun D (1998) The Role of Funding Agencies in the Cognitive Development of Science. Research Policy 27(8): 807821.

Brown N (2009) Beasting the Embryo: The Metrics of Humanness in the Transpecies Embryo Debate. BioSocieties 4(2): 147163.

Bubela T, Strotmann A, Adams R \& Morrison S (2010) Commercialization and Collaboration: Competing Policies in Publicly Funded Stem Cell Research? Cell Stem Cell 7(1): 25-30.

Caufield T (2010) Stem Cell Research and Economic Promises. The Journal of Law, Medicine \& Ethics 38(2): 303-313.

Cerny PG (1997) Paradoxes of the Competition State: the Dynamics of Political Globalization. Government and Opposition 32(2): 251-274.

Daley GQ (2012) The Promise and Perils of Stem Cell Therapeutics. Cell Stem Cell 10(6): 740-749.

Daston L (1995) The Moral Economy of Science. Osiris 10: 2-24.

Eriksson L \& Webster A (2008) Standardizing the Unknown: Practicable Pluripotency as Doable Futures. Science as Culture 17(1): 57-69.

Etzkowitz H \& Leydesdorff L (1997) Universities and the Global Knowledge Economy: A Triple Helix of UniversityIndustry-Government Relations. London: Pinter.

Fairclough N (1995) Critical Discourse Analysis. London: Longman.

Gibbons M (1994) The New Production of Knowledge: The Dynamics of Science and Research in Contemporary Societies. London: Sage.
Gottweis H, Salter B \& Waldby C (2009) The Global Politics of Human Embryonic Stem Cell Science: Regenerative Medicine in Transition. Basingstoke: Palgrave Macmillan.

Hall S (1996) Introduction: Who Needs Identity. In: Hall S \& Du Gay P (eds) Questions of Cultural Identity. London: Sage, 1-17.

Hansen J \& Metzler I (2012) Governing Bioobjects: a Research Agenda. Croatian Medical Journal 53(1): 80-82.

Haraway DJ (1997) Modest_Witness@ Second_Millennium.FemaleMan_ Meets_OncoMouse: Feminism and Technoscience. New York: Routledge.

Holmberg T, Schwennesen N \& Webster A (2011) Bio-objects and the Bioobjectification Process. Croatian Medical Journal 52(6): 740-742.

Jessop B (2002) The Future of the Capitalist State. Cambridge: Polity.

Kohler RE (1994) Lords of the Fly: Drosophila Genetics and The Experimental Life. Chicago, IL: Univiversity of Chicago Press.

Lau D, Ogbogu U, Taylor B, Stafinski T, Menon D \& Caulfield T (2008) Stem Cell Clinics Online: the Direct-to-Consumer Portrayal of Stem Cell Medicine. Cell Stem Cell 3(6): 591-594.

Lave R, Mirowski P \& Randalls S (2010) Introduction: STS and Neoliberal Science. Social Studies of Science 40(5): 659-675.

Martin PA, Brown N \& Kraft, A. (2008) From Bedside to Bench? Communities of Promise, Translational Research and the Making of Blood Stem Cells. Science as Culture 17(1): 29-41.

Martin PA, Coveney C, Kraft A, Brown N \& Bath P (2006) Commercial Development of Stem Cell Technology: Lessons from the Past, Strategies for the Future. Regenerative Medicine 1(6): 801-807. 
Mirowski P \& Sent EM (2002) Science Bought and Sold: Essays in the Economics of Science. Chicago, IL: University of Chicago Press.

Mirowski P \& van Horn R (2005) The Contract Research Organization and the Commercialization of Scientific Research. Social Studies of Science 35(4): 503-548.

Moore K, Kleinman DL, Hess D \& Frickel $S$ (2011) Science and Neoliberal Globalization: a Political Sociological Approach. Theory and Society 40(5): 505532.

Mulinari S (2013). Regulating Drug Information in Europe: a Pyrrhic Victory for Pharmaceutical Industry Critics? Sociology of Health \& Illness 35(5): 761777.

Pestre D (2005) The Technosciences Between Markets, Social Worries and the Political: How to Imagine a Better Future? In: Nowotny H (ed) The Public Nature of Science Under Assault: Politics, Markets, Science and the Law. Berlin: Springer, 29-52.

Plagnol AC, Rowley E, Martin P \& Livesy F (2009) Industry Perceptions of Barriers to Commercialization of Regenerative Medicine Products in the UK. Regenerative Medicine 4(4): 549-559.

Rickne A \& Sandström A (2009) Swedish Possibilities Within Tissue Engineering and Regenerative Medicine. Stockholm, Sweden: VINNOVA.

Rose N (2007) The Politics of Life Itself: Biomedicine, Power, and Subjectivity in the Twenty-First Century. Princeton: Princeton University Press.

Salter B (2008) Governing Stem Cell Science in China and India: emerging economies and the global politics of innovation. New Genetics and Society 27(2): 145-159.

Salter B \& Salter C (2007) Bioethics and the Global Noral Economy: the Cultural Politics of Human Embryonic Stem Cell Science. Science, Technology \& Human Values 32(5): 554-581.
Salter B \& Salter C (2010) Governing Innovation in the Biomedicine Knowledge Economy: Stem Cell Science in the USA. Science and Public Policy 37(2): 87-100.

Sanders CB \& Miller FA (2010) Reframing Norms: Boundary Maintenance and Partial Accommodations in the Work of Academic Technology Transfer. Science and Public Policy 37(9): 689-701.

Sismondo S (2009) Ghosts in the Machine: Publication Planning in the Medical Sciences. Social Studies of Science 39(2): 171-198.

Sismondo S (2010) An Introduction to Science and Technology Studies. Chichester, West Sussex: Wiley-Blackwell. Slaughter S \& Rhoades G (1993) Changes in Intellectual Property Statutes and Policies at a Public University: Revising the Terms of Professional Labor. Higher Education 26(3), 287-312.

Slaughter S \& Rhoades G (2004) Academic Capitalism and the New Economy: Markets, State, and Higher Education. Baltimore: Johns Hopkins University Press.

Styhre A \& Sundgren M (2011) Venturing into the Bioeconomy: Professions, Innovation, Identity. Basingstoke, Hampshire: Palgrave Macmillan.

Sunder Rajan K (2006) Biocapital: The Constitution of Postgenomic Life. Durham: Duke University Press.

Swedish Government (2008) Research and Innovation Bill 2009-2012. A Boost to Research and Innovation. Government Bill 2008/09:50. Stockholm, Sweden.

Swedish Government (2012) Research and Innovation Bill 2013-2016. Government Bill 2012/13:30. Stockholm, Sweden.

Swedish Research Council (2009a) Call for Grant Applications: Strategic Research Areas. Stockholm, Sweden: Swedish Research Council. 
Swedish Research Council (2009b) Expertpanelernas Slutgiltiga Yttranden Per Område [Expert Panels' Final Pronouncement Per Area]. Stockholm, Sweden: Swedish Research Council.

Tamminen S \& Vermeulen N (2012) Bioobjects and Generative Relations. Croatian Medical Journal 53(2): 198-200.

Tuunainen J \& Knuuttila T (2009) Intermingling Academic and Business Activities: A New Direction for Science and Universities? Science Technology \& Human Values 34(6): 684-704.

Vermeulen N, Tamminen S \& Webster A (eds) (2012) Bio-Objects: Life in the 21st Century. Farnham, UK: Ashgate Publishing Ltd.

VINNOVA [Sweden's Innovation Agency] (2011) Analys av Förutsättningar för Innovation inom de Strategiska Forskningsområdena [Analysis of the Potential for Innovation in the Strategic Research Areas]. Stockholm, Sweden: VINNOVA.

Wainwright SP \& Williams C (2008) Spaces of Speech and Places of Performance: An Outline of a Geography of Science Approach to Embryonic Stem Cell Research and Diabetes. New Genetics and Society 27(2): 161-173.

Waldby C (2002) Stem Cells, Tissue Cultures and the Production of Biovalue. Health, 6(3): 305-323.

Webster A (ed) (2013) The Global Dynamics of Regenerative Medicine: A Social Science Critique. Basingstoke, UK: Palgrave Macmillan.
Shai Mulinari

shai.mulinari@soc.lu.se

Lund University

Shai Mulinari carried out this work as part of a PostDoc at the Department of Science, Environment and Society, Malmö University, Sweden. Currently Mulinari is Researcher at the Department of Sociology, and Unit of Social Epidemiology, at Lund University, Sweden. Mulinari holds a PhD in Developmental Biology from Lund University. His more recent research focuses on the history of psychiatric research, regulation of the pharmaceutical industry, stem cell science policy, and public health.

Tora Holmberg

tora.holmberg@ibf.uu.se

Uppsala University

Tora Holmberg is a Senior Lecturer and Associate Professor at the Department of Sociology, and the Institute for Housing and Urban Research, Uppsala University, Sweden. Her research interests include human/animal relations in various contexts, and her cultural sociology approach combines STS, urban sociology, animal studies and feminist theory.

Malin Ideland

malin.ideland@mah.se

Malmö University

Malin Ideland is Professor in Educational sciences with specialty in Ethnology at Malmö University. Her research interests concern a) cultural perspectives on modern biotechnologies, e.g. transgenic animals and stem cell research; b) critical studies on science and sustainability education. 